\title{
Comparison of the efficacy of long-term treatment of primary monosymptomatic nocturnal enuresis of varying severity using traditional methods
}

\author{
*Kirill Kosilov ${ }^{1}$, Irina Kuzina ${ }^{1}$, Vladimir Kuznetsov ${ }^{2}$, Yuliya Gainullina ${ }^{1}$, Liliya Kosilova ${ }^{3}$, Alexandra \\ Prokofyeva $^{1}$, Sergey Loparev ${ }^{4}$
}

Sri Lanka Journal of Child Health, 2018; 47: 249-256

\begin{abstract}
Background: Primary monosymptomatic nocturnal enuresis (PMNE) is a pathological state where the patient has no problem with bladder control in the waking state but does not awake from the urge to urinate. Very little is known about the prognostic factors regarding effective treatment of PMNE using methods recommended by the International Children's Continence Society.
\end{abstract}

Objective: To compare the efficacy of long term treatment of PMNE using alarm intervention (AI) and desmopressin in children and adolescents and also to study the impact on it of the severity of disease, age and socio-economic factors.

Method: Study was conducted from $15^{\text {th }}$ January to $30^{\text {th }}$ October, 2016 in the Far Eastern Federal University (Vladivostok) in children 7 to 14 years old having PMNE. At the preliminary stage, the clinical, socio-economic and demographic characteristics of the children were noted. All patients had blood and urine tests done and the level of antidiuretic hormone was determined. To exclude a hyperactive bladder, uroflowmetry and a questionnaire survey of $\mathrm{OABq}-\mathrm{SF}$ were used. Monitoring of changes in the number of episodes of enuresis (EE) and independent awakenings was carried out using a voiding diary. In the active phase of the study, patients from group A underwent treatment by $\mathrm{AI}$ and patients from group $B$ received desmopressin $0.4 \mathrm{mg}$ per day.

Results: There were 339 children aged 7 to 14 years with PMNE during the study period. Group A

${ }^{1}$ Far Eastern Federal University, Russian Federation, ${ }^{2}$ Pacific State Medical University, Russian Federation, ${ }^{3}$ Medical Association No. 2 of Vladivostok-city, Russian Federation, ${ }^{4}$ Polyclinic No. 3 of Vladivostok-city

*Correspondence: oton2000@mail.ru

(Received on 03 October 2017: Accepted after revision on 13 December 2017)

The authors declare that there are no conflicts of interest

Personal funding was used for the project.

Open Access Article published under the Creative

Commons Attribution CC-BY (c) () comprised 162 children treated with AI. At the end of the 4-month course, absence of PMNE was noted in $82.7 \%$ patients and after 6 months in $74.7 \%$ children. Group B comprised 177 children treated with desmopressin $0.4 \mathrm{mg} / \mathrm{day}$. In group B the absence of PMNE was noted 4 months after the start of the experiment in $72.9 \%$ of children and after six months in $67.2 \%$ of children. Construction of a two-stage regression model and carrying out partial F-tests established that in group A, the EE level was significantly associated with age $(p<0.05)$, and the severity of symptoms $(p<0.01)$. In group $\mathrm{B}$, the EE level was associated with age $(p<0.05)$ and severity of symptoms $(p<0.05)$. In addition, it was found that the effectiveness of AI was significantly higher in children who had a greater number of independent awakenings before treatment $(\mathrm{p} \leq 0.01)$.

Conclusions: Use of AI in the treatment of PMNE is significantly associated with the number of independent awakenings. Use of both AI and desmopressin are significantly associated with age and severity of symptoms of PMNE. Socioeconomic and demographic factors have no significant influence on treatment outcomes of PMNE.

DOI: http://dx.doi.org/10.4038/sljch.v47i3.8548

(Key words: Enuresis, alarm intervention, desmopressin, effectiveness, predictors, treatment)

\section{Introduction}

Primary monosymptomatic nocturnal enuresis (PMNE) is a pathological state where the patient has no problem with bladder control in the waking state but does not awake from the urge to urinate. The incidence of PMNE in the population is 15$16 \%$ in the $5-9$ year olds, $4-6 \%$ in the $10-12$ year olds, about $1.5 \%$ in 14 -year-olds and less than $1 \%$ among adults ${ }^{1-5}$. The aetiological factors of primary enuresis include delay in forming a nerve urination regulatory mechanism, disturbances of antidiuretic hormone synthesis, violation of the sleep-wake cycle and sleep characteristics or some other pathological condition ${ }^{6-8}$.

International Children's Continence Society $(\mathrm{ICCS})^{9}$ and National Clinical Guideline Centre 
(NCGC), UK, in 2012 presented the clinical recommendations for diagnosis and treatment of PMNE. According to these, the main methods for active treatment of enuresis are alarm intervention (AI) and desmopressin. Both methods are considered safe and their effectiveness is estimated at $60-90 \% \%^{6,10}$. AI entails the use of special alarm devices that awaken the patient at the beginning of urination $^{11}$. Desmopressin reduces night diuresis, thereby reducing the number of 'wet' nights ${ }^{12}$. However, search for new effective treatment for PMNE continues. In particular, antimuscarinic drugs (AMDs) have been tested ${ }^{13}$. It is known that AMDs increase the volume of the bladder and time between urges to urinate ${ }^{14-16}$. However, results from the use of AMDs in the treatment of enuresis are contradictory $^{17}$. For the treatment of PMNE in clinical practice, AI, desmopressin and their combination continue to be used ${ }^{18}$. According to some researchers ${ }^{19}$ and our earlier studies ${ }^{20,21}$, effect of treatment with AI comes later than when using desmopressin or a combination of AI and desmopressin. Combination therapy using AI and desmopressin is not significantly better than using each method separately.

In addition, studies of predictors for treatment effectiveness with each method are scarce according to Scopus, WoS and PubMed. In the literature, there is fragmented evidence that the efficacy of desmopressin is higher in older children having a small number of 'wet nights' and nocturnal polyuria ${ }^{22}$. Other researchers indicate that the efficacy of desmopressin is related to the frequency and severity of symptoms, motivation of children $^{19,23}$ and adherence to treatment ${ }^{24}$. These results appear rational but have so far not been carried out in a comprehensive study of predictors of effective treatment to PMNE, taking into account the influence of the initial clinical, demographic, socio-economic factors on the outcome of therapy using each particular method.

\section{Objectives}

To compare the efficacy of long term treatment of PMNE using alarm intervention (AI) and desmopressin in children and adolescents and also to study the impact on it of the severity of disease, age and socio-economic factors.

\section{Method}

The study was conducted from $15^{\text {th }}$ January, 2016 to $30^{\text {th }}$ October, 2016 in the urological centre of the city polyclinic No. 3 (Vladivostok), in the diagnostic department of Children's Medical Association No. 2 (Vladivostok) and Far Eastern Federal University (Vladivostok) on children aged 7 to 14 years with PMNE. The children were randomly divided into two groups: Group A comprised children treated by alarm intervention
(AI) and Group B comprised children treated with desmopressin $0.4 \mathrm{mg} /$ day. To randomize patients, the method of blind random sample was used. The study included patients with urination during sleep (at least twice a week) $)^{6,7,9}$, who previously had not used AI or taken desmopressin. Clinical, socioeconomic and demographic characteristics of the children are shown in Table 1.

A detailed history was taken in children who complained of urination during sleep of demographic data and socio-economic status (SES) of the children and their families. Laboratory tests included blood tests, urinalysis, stool analysis and measurement of urinary flow rate using uroflowmetry. Using the overactive bladder questionnaire (OABq-SF), the presence of overactive bladder (OAB) symptoms was detected. Throughout the study, children, together with their parents or caretakers, filled out the voiding diary, supplemented with graphs that indicated the number of episodes of enuresis (EE), the amount of fluid consumed, the numbers of self-awakening (SA) at urge to urinate, and also the report on treatment ${ }^{25}$.

Exclusion criteria were the presence of $\mathrm{OAB}$, acute inflammatory disease, chronic disease in the active stage and changed level of antidiuretic hormone in the blood (the norm was taken as $<1.5 \mathrm{ng} / \mathrm{L}$ with an osmolarity level of 270$280 \mathrm{mosm} / \mathrm{L}$ ). The treatment phase, according to ICCS recommendations, lasted 16 weeks. In group A the signal system of Wet Stop/ BYE-WET, PALCO LABS, Inc (USA) was used. Before treatment, patients, their parents, or caregivers were instructed about guidance on the use of alarm systems. In group B the therapeutic agent used was desmopressin in a dose of $0.4 \mathrm{mg}$ once a day. At this stage, patients with the help of their parents filled out a voiding diary, information from which was analysed in 8 weeks. Written informed consent was obtained from all parents prior to their children participating in the experiment. The total time of observation of the children was $16+8=24$ weeks. The algorithm for the study is shown in Figure 1. The study protocol has been approved by the Ethics Committee of the Far Eastern Federal University.

Next, we assessed the effect of sex, age, presence of siblings, family completeness (one or two parents), family income level, level of education of parents, place of residence, severity of enuresis symptoms, number of 'dry nights' per week, number of urinations per day, number of selfawakenings at the urge to urinate and the clinical characteristics of urination on the effectiveness of the therapy. Under the severe symptoms of enuresis, we understood the availability of more than 5 episodes of enuresis per week. 
Table 1: Clinical, demographic and socio-economic characteristics of children with PMNE

\begin{tabular}{|c|c|c|c|}
\hline Variable & $\begin{array}{c}\text { Group A }(n=162) \\
\text { Mean (SD) or No. }(\%)\end{array}$ & $\begin{array}{c}\text { Group B }(n=177) \\
\text { Mean (SD) or No. }(\%)\end{array}$ & $\begin{array}{c}\text { Total }(n=339) \\
\text { Mean (SD) or No. }(\%)\end{array}$ \\
\hline $\begin{array}{l}\text { Gender } \\
\text { Male } \\
\text { Female }\end{array}$ & $\begin{array}{l}87(53.7) \\
75(46.3)\end{array}$ & $\begin{array}{l}92(51.9) \\
85(48.1)\end{array}$ & $\begin{array}{l}179(52.8) \\
160(47.2)\end{array}$ \\
\hline Siblings & $1.3(0.7)$ & $1.4(0.4)$ & $1.4(0.7)$ \\
\hline Full family (mother \& father) & $113(69.7)$ & $137(77.4)$ & $250(73.7)$ \\
\hline $\begin{array}{l}\text { Age group } \\
6-8 \text { years } \\
9-11 \text { years } \\
12-14 \text { years }\end{array}$ & $\begin{array}{l}57(35.2) \\
54(33.3) \\
51(31.5) \\
\end{array}$ & $\begin{array}{l}55(31.1) \\
59(33.3) \\
63(35.6) \\
\end{array}$ & $\begin{array}{l}112(33.0) \\
113(33.3) \\
114(33.6) \\
\end{array}$ \\
\hline $\begin{array}{l}\text { Place of residence } \\
\text { Village } \\
\text { City }\end{array}$ & $\begin{array}{l}83(51.2) \\
79(48.8) \\
\end{array}$ & $\begin{array}{l}88(49.7) \\
89(50.3) \\
\end{array}$ & $\begin{array}{l}171(50.4) \\
168(49.5)\end{array}$ \\
\hline $\begin{array}{l}* \text { Average annual family income } \\
<\$ 2,830 \\
\$ 2,830-4,400 \\
\$ 4,400-15,884 \\
\$ 15,884+\end{array}$ & $\begin{array}{l}23(14.2) \\
78(48.1) \\
34(20.9) \\
27(16.7)\end{array}$ & $\begin{array}{l}14(07.9) \\
85(48.0) \\
31(17.5) \\
47(26.5)\end{array}$ & $\begin{array}{c}37(10.9) \\
163(48.1) \\
65(19.1) \\
74(21.8)\end{array}$ \\
\hline $\begin{array}{l}* * \text { Parental education } \\
<\text { High School } \\
\text { High School } \\
\text { University degree } \\
\text { Master's degree or }>\end{array}$ & $\begin{array}{l}09(05.5) \\
63(38.8) \\
79(48.7) \\
11(06.7) \\
\end{array}$ & $\begin{array}{l}05(02.8) \\
84(47.4) \\
81(45.7) \\
07(03.9)\end{array}$ & $\begin{array}{c}14(04.1) \\
147(43.4) \\
160(47.2) \\
18(05.3) \\
\end{array}$ \\
\hline Leucocytes $\times 10^{9} / \mathrm{L}$ & $7.1(2.0)$ & $6.5(2.5)$ & $6.9(2.3)$ \\
\hline$P P A F, \mathrm{pmol} / L$ & $3.71(2.44)$ & $3.98(3.06)$ & $4.83(2.82)$ \\
\hline $\begin{array}{l}\text { Number of episodes enuresis / } \\
\text { week }\end{array}$ & $3.6(0.9)$ & $4.1(1.1)$ & $3.9(1.3)$ \\
\hline $\begin{array}{l}\text { Number of episodes self- } \\
\text { awakening }\end{array}$ & $4.8(1.5)$ & $5.5(1.8)$ & $5.2(1.9)$ \\
\hline Number of dry nights & $3.9(2.3)$ & $3.6(1.7)$ & $3.8(2.1)$ \\
\hline $\begin{array}{l}* * * \text { Children with severe } \\
\text { symptoms }\end{array}$ & $102(62.9 \%)$ & $126(71.2 \%)$ & $228(67.2 \%)$ \\
\hline $\begin{array}{l}\text { Average number of urination/ } \\
\text { day }\end{array}$ & $7.8(1.7)$ & $7.2(3.1)$ & $7.5(3.7)$ \\
\hline $\begin{array}{l}\text { Average flow rate } \mathrm{ml} / \mathrm{sec} \\
\text { (uroflowmetry) }\end{array}$ & $12.4(6.9)$ & $13.6(4.7)$ & $13.1(6.2)$ \\
\hline $\begin{array}{l}\text { Maximum flow rate } \mathrm{ml} / \mathrm{sec} \\
\text { (uroflowmetry) }\end{array}$ & $14.7(4.6)$ & $14.9(5.9)$ & $14.7(7.4)$ \\
\hline $\begin{array}{l}\text { Bladder volume, } m l \\
\text { (uroflowmetry) }\end{array}$ & $126.7(23.6)$ & $133(17.9)$ & $129.6(21.7)$ \\
\hline
\end{tabular}

$* \$ 2,830$ - average minimum wage at time of study $x 2, \$ 4,400$ - average living wage over same period $x 2$ and

$\$ 16,455$ - average wage level in all spheres of economics over 2016 year; **At least one of the parents; ***More than 5 episodes a week

PMNE: primary monosymptomatic nocturnal enuresis, SD: standard deviation, PPAF: posterior pituitary antidiuretic factor

The variance analysis (ANOVA) was used to estimate the reliability of the differences between mean values of compared parameters. Using the weighted least squares (WLS), we conducted a multivariate regression analysis to identify the relationships between SES variables, anthropological and clinical parameters, and the number of episodes of enuresis after treatment with different methods. Selection of incoming variable in the model specification was carried out by comparing the mean squares of regressions with mean squared errors (Fisher criterion). However, to explore the possibility of nonlinear dependencies, the final model included both incremental and nonincreasing variables. All statistical analyses were performed using SAS version 8.0.2. $\mathrm{p}<0.05$ was considered statistically significant.

\section{Results}

There were 339 children aged 7 to 14 years with PMNE during the study period. Group A comprised 162 children treated with AI. Group B comprised 177 children treated with reboxetine $0.4 \mathrm{mg} /$ day. Table 2 presents the stepwise regression results of the number for episodes of enuresis (EE) under the influence of independent variables. 
Table2: Number of episodes of enuresis regressed on each SES, demographic and clinical parameters separately and full sample $(n=339)$

\begin{tabular}{|c|c|c|c|c|}
\hline \multirow[t]{2}{*}{ Variable } & \multicolumn{2}{|c|}{$\begin{array}{l}\text { Measures on each variable } \\
\text { separately }\end{array}$} & \multicolumn{2}{|c|}{ Measures for the full sample } \\
\hline & $\begin{array}{c}\text { Group A } \\
(n=162) \\
\text { Estimate (SD) }\end{array}$ & $\begin{array}{c}\text { Group B } \\
(n=177) \\
\text { Estimate (SD) }\end{array}$ & $\begin{array}{c}\text { Group A } \\
(n=162) \\
\text { Estimate (SD) }\end{array}$ & $\begin{array}{c}\text { Group B } \\
(n=177) \\
\text { Estimate (SD) }\end{array}$ \\
\hline Gender (Female) & $-0.13(0.07)$ & $-0.32(0.14)$ & $-0.21(0.18)$ & $-0.13(0.13)$ \\
\hline $\begin{array}{l}\text { Siblings } \\
1 \text { or less } \\
\text { More than } 1\end{array}$ & $\begin{array}{c}\text { Reference group } \\
0.25(0.11)\end{array}$ & $\begin{array}{c}\text { Reference group } \\
0.31(0.13)\end{array}$ & $\begin{array}{c}\text { Reference group } \\
0.03(0.016)\end{array}$ & $\begin{array}{c}\text { Reference group } \\
0.041(0.31)\end{array}$ \\
\hline Full family (mother and father) & $-0.47(0.29)$ & $-0.10(0.17)$ & $-0.18(0.14)$ & $-0.9(0.8)$ \\
\hline $\begin{array}{l}\text { Age group (years) } \\
6-8 \\
9-11 \\
12-14 \\
\end{array}$ & $\begin{array}{l}\text { Reference group } \\
-0.95 * *(0.26) \\
-1.33^{* *}(0.32)\end{array}$ & $\begin{array}{l}\text { Reference group } \\
-1.04 *(0.36) \\
-1.57 * *(0.39)\end{array}$ & $\begin{array}{l}\text { Reference group } \\
-0.79 *(0.23) \\
-0.89 *(0.46)\end{array}$ & $\begin{array}{l}\text { Reference group } \\
-0.51(0.49) \\
-0.90 *(0.52) \\
\end{array}$ \\
\hline $\begin{array}{l}\text { Place of residence } \\
\text { City } \\
\text { Village }\end{array}$ & $\begin{array}{c}\text { Reference group } \\
0.07(0.05)\end{array}$ & $\begin{array}{c}\text { Reference group } \\
0.11(0.04)\end{array}$ & $\begin{array}{c}\text { Reference group } \\
0.03(0.08)\end{array}$ & $\begin{array}{c}\text { Reference group } \\
0.04(0.04)\end{array}$ \\
\hline $\mathrm{R}^{2}$ & $7.9 \%$ & $16.0 \%$ & $17.8 \%$ & $10.3 \%$ \\
\hline $\begin{array}{l}\text { Parent education (At least one parent) } \\
<\text { High school } \\
\text { High school } \\
>\text { High school (University/ Master's } \\
\text { degree) }\end{array}$ & $\begin{array}{c}-0.12(0.03) \\
-0.12(0.07) \\
\text { Reference group }\end{array}$ & $\begin{array}{c}-0.22(0.15) \\
-0.31(0.13) \\
\text { Reference group }\end{array}$ & $\begin{array}{c}-0.09(0.01) \\
-0.16(0.08) \\
\text { Reference group }\end{array}$ & $\begin{array}{c}-0.24(0.10) \\
-0.13(0.05) \\
\text { Reference group }\end{array}$ \\
\hline $\mathrm{R}^{2}$ & $11.4 \%$ & $16.7 \%$ & $18.9 \%$ & $19.2 \%$ \\
\hline $\begin{array}{l}\text { Annual family income } \\
<\$ 2830 \\
\$ 2830-4400 \\
\$ 4400-16455 \\
\$ 7942+\end{array}$ & $\begin{array}{c}-0.98 *(0.035) \\
-0.69(0.047) \\
-0.19(0.09) \\
\text { Reference group }\end{array}$ & $\begin{array}{c}-0.65(0.18) \\
-0.33(0.24) \\
-0.40(0.25) \\
\text { Reference group }\end{array}$ & $\begin{array}{c}-0.38(0.09) \\
-0.32(0.06) \\
-0.14(0.18) \\
\text { Reference group }\end{array}$ & $\begin{array}{c}-0.45(0.18) \\
-0.23(0.20) \\
-0.23(0.15) \\
\text { Reference group }\end{array}$ \\
\hline $\mathrm{R}^{2}$ & $9.2 \%$ & $8.8 \%$ & $12.0 \%$ & $3.9 \%$ \\
\hline $\begin{array}{l}\begin{array}{l}\text { Severe symptoms } \\
\text { week }\end{array}\end{array}$ & $-2.15 * *(0.61)$ & $-1.83 * *(0.57)$ & $-1.58 * *(0.45)$ & $-0.96 *(0.27)$ \\
\hline $\mathrm{R}^{2}$ & $19.0 \%$ & $17.9 \%$ & $25.1 \%$ & $18.9 \%$ \\
\hline $\begin{array}{l}\text { "Dry" night } \\
\leq 3.8 \\
>3.8\end{array}$ & $\begin{array}{c}0.52(0.13) \\
\text { Reference group }\end{array}$ & $\begin{array}{c}0.34(0.18) \\
\text { Reference group }\end{array}$ & $\begin{array}{c}0.57(0.12) \\
\text { Reference group }\end{array}$ & $\begin{array}{c}0.29(0.26) \\
\text { Reference group }\end{array}$ \\
\hline $\mathrm{R}^{2}$ & $9.3 \%$ & $14.3 \%$ & $13.7 \%$ & $11.9 \%$ \\
\hline $\begin{array}{l}\text { Urination/day } \\
\leq 7.5 \\
>7.5\end{array}$ & $\begin{array}{l}\text { Reference group } \\
\quad-0.88 *(0.21)\end{array}$ & $\begin{array}{l}\text { Reference group } \\
-1.07 * *(0.39)\end{array}$ & $\begin{array}{l}\text { Reference group } \\
-0.76(0.56)\end{array}$ & $\begin{array}{l}\text { Reference group } \\
\quad-0.69(0.37)\end{array}$ \\
\hline $\mathrm{R}^{2}$ & $6.7 \%$ & $10.6 \%$ & $7.9 \%$ & \\
\hline $\begin{array}{l}\text { Self-awakening } \\
\leq 5.2 \\
>5.2\end{array}$ & $\begin{array}{l}\text { Reference group } \\
-2.21 * *(0.62)\end{array}$ & $\begin{array}{l}\text { Reference group } \\
\quad-0.57(0.44)\end{array}$ & $\begin{array}{l}\text { Reference group } \\
-1.17^{* *}(0.31)\end{array}$ & $\begin{array}{l}\text { Reference group } \\
\quad-0.33(0.22)\end{array}$ \\
\hline $\mathrm{R}^{2}$ & $25.6 \%$ & $15.8 \%$ & $12.1 \%$ & $16.6 \%$ \\
\hline $\begin{array}{l}\text { Average flow rate } \mathrm{ml} / \mathrm{sec} \\
\leq 13.1 \\
>13.1\end{array}$ & $\begin{array}{l}\text { Reference group } \\
\quad-0.21(0.15)\end{array}$ & $\begin{array}{l}\text { Reference group } \\
\quad-0.35(0.17)\end{array}$ & $\begin{array}{l}\text { Reference group } \\
-0.12(0.10)\end{array}$ & $\begin{array}{l}\text { Reference group } \\
\quad-0.10(0.13)\end{array}$ \\
\hline $\mathrm{R}^{2}$ & $6.6 \%$ & $9.2 \%$ & $8.1 \%$ & $7.5 \%$ \\
\hline $\begin{array}{l}\text { Bladder volume, } m l \\
\leq 129 \\
>129\end{array}$ & $\begin{array}{l}\text { Reference group } \\
\quad-0.36(0.17)\end{array}$ & $\begin{array}{l}\text { Reference group } \\
\quad-0.24(0.20)\end{array}$ & $\begin{array}{l}\text { Reference group } \\
-0.27(0.16)\end{array}$ & $\begin{array}{l}\text { Reference group } \\
\quad-0.15(0.14)\end{array}$ \\
\hline $\mathrm{R}^{2}$ & $12.4 \%$ & $8.8 \%$ & $9.5 \%$ & $13.7 \%$ \\
\hline
\end{tabular}

SES - socio-economic status; SD - standard deviation; 3.8 - average number of "dry" nights /week in the sample; 7.5 - average number of urination /day; 5.2 - number of episodes of self-awakening/week in the sample; $* p<0.05$, ** $p<0.01$.

The left part of the table presents the analysis results of the first step of regression for each anthropological, demographic, socioeconomic and clinical parameter. The number of EE in 6-8-yearold children after treatment became significantly less than in 9-11 year-olds (Group A $\mathrm{p}<0.001$, Group B $\mathrm{p}<0.005$ ), and in 12-14 year-olds (Group A $p<0.001$; Group B $p<0.001$ ). In both groups the number of EE after treatment was significantly lower in patients with severe symptoms than 
among other patients (Group A p $<0.001$; Group B $p<0.001$ ). The number of $E E$ in patients with higher number of urination after treatment decreased in Group A $(p<0.05)$, and even more significantly in group B $(p<0.001)$, as compared to control. In group $\mathrm{A}$, the number of $\mathrm{EE}$ in children who often woke up independently (with urge to urinate) at the start of the study was significantly lower after treatment than in the rest of the patients $(p<0.01)$; in group $B$, no such difference was found ( $p>0.05)$.

The conjugacy of SES parameters and other variables was studied using the level of EE and was also tested by using partial F-tests (not shown). Partial F-tests have confirmed that each variable value such as age, the severity of PMNE symptoms, the frequency of daytime urination, the number of episodes of independent awakenings, makes a significant contribution to the explanation of variance of EE.

In the right of the table are presented results of regression of $\mathrm{EE}$ for each anthropological, demographic, socio-economic and clinical parameter, taking into account the influence of all variables. Partial F-tests (not given) showed that in group $\mathrm{A}$, the level of $\mathrm{EE}$ is associated with age $(p<0.05)$, the number of independent awakenings $(p<0.01)$ and the severity of symptoms $(p<0.01)$. In group $\mathrm{B}$, the EE level was also associated with age $(p<0.05)$ and severity of symptoms $(p<0.05)$.

Figure 1 demonstrates the dynamics of episodes of enuresis, independent awakenings with urge to urinate, and the number of 'dry' nights (for children from each group).

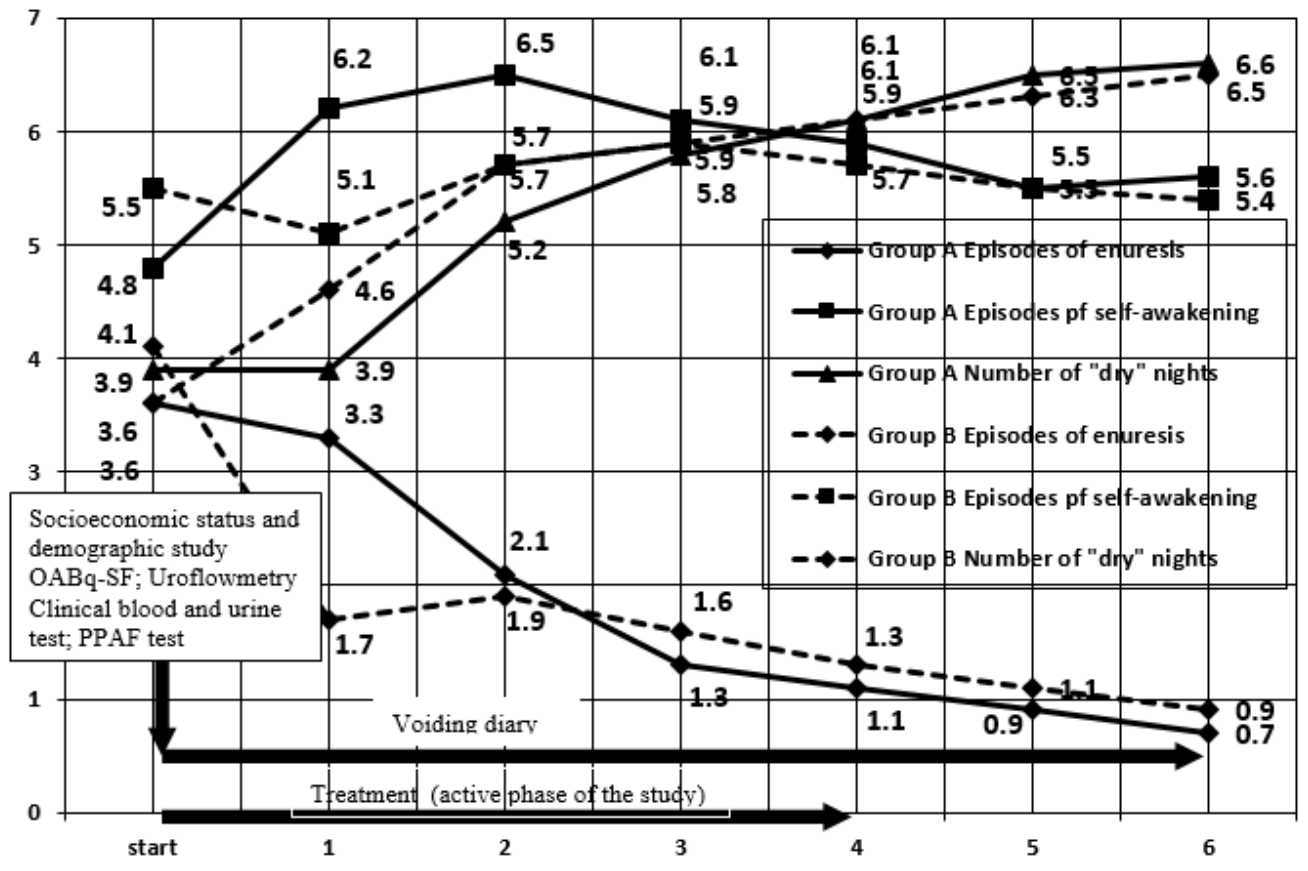

Figure 1: The change in frequency of episodes of enuresis, self-awakening and "dry" nights (per week) in group $A(n=162 ;$ Alarm therapy) and $B(n=177$; receiving Desmopressin).

After a month of treatment, the number of $\mathrm{EE}$ decreased sharply in children receiving desmopressin but remained almost unchanged in children who were prescribed AI therapy (3.3 vs. $1.7, \mathrm{p}<0.05)$. However, in the period from 2 to 6 months of observation, differences between the numbers of EEs in the 2 groups remained within a range of statistical error. The number of episodes of independent awakenings and 'dry' nights in groups $A$ and $B$ increased slightly during the observation period but this was statistically insignificant.

In group $\mathrm{A}$, the absence of PMNE was noted 4 months after the start of the experiment (the end of active phase) in $82.7 \%$ of children and after 6 months (the end of observation) in $74.7 \%$ of children. In group B the absence of PMNE was noted 4 months after start of experiment in $72.9 \%$ of children and after six months in $67.2 \%$ of children. Only $3(0.9 \%)$ persons refused to participate in the study during it (all from group B).

Comparative analysis showed that the average level of investigated variables in group B was homogeneous for the complete and incomplete composition of the group. Children in group A did not complain about side effects during treatment. In Group B, 11 (6.2\%) children complained of dry mouth and nausea, and in $2(1.1 \%)$ cases headache. All the symptoms were short-term reactions and disappeared on their own without the drug being withdrawn. 


\section{Discussion}

We carried out the study of efficacy for PMNE treatment in two homogeneous groups of children using alarm intervention and desmopressin. Our results agree with data of other authors, and with our earlier observations on effectiveness of these treatment methods ${ }^{17,18,21}$. Group A: After the 16 month course of AI, symptoms of PMNE were absent in $82.7 \%$ of children and after another 2 months of observation in $74.7 \%$. Group B: After the 16 month course of desmopressin, symptoms of PMNE were absent in $72.9 \%$ of children and after another 2 months of observation in $67.2 \%$. Reduction in the percentage of patients with no symptoms of enuresis two months after the end of treatment is statistically not significant ( $p>0.05)$ and, in our opinion, may indicate good safety and stability of the therapeutic effect when using both AI and desmopressin.

Group A comprised 162 children treated with AI. At the end of the 4-month course, absence of PMNE was noted in $82.7 \%$ patients and after 6 months in $74.7 \%$ children. Group B comprised 177 children treated with desmopressin $0.4 \mathrm{mg} /$ day 0.4 $\mathrm{mg}$ /day. In group B the absence of PMNE was noted 4 months after start of experiment in $72.9 \%$ of children and after six months in $67.2 \%$ of children.

However, the main purpose of this study was to determine possible predictors for treatment effectiveness among various anthropological, demographic, socio-economic and clinical factors. As a result of multivariate regression analysis, we found that the effectiveness of both methods of treatment depends on age. Among younger patients, the treatment was more effective, and the frequency of enuresis after treatment was significantly less than in 9-11 year children and 1214 year old children $(\mathrm{p}<0.05)$. This result contradicts the data obtained by Van Herzeele et al. in 2015 in children receiving desmopressin ${ }^{21}$. The authors found better results among adolescents. However, the authors note that the selection was characterized by a low maximum volume of the urination, and an increased frequency of the urination, which probably indicates the presence of signs in children of overactive bladder (OAB). In our study, all children with signs of $\mathrm{OAB}$ were excluded from selection at the preliminary stage. At the same time, it is known that features of growth and development of the central nervous system provide a more effective consolidation of conditioned reflex connections at an early age. Perhaps this explains the best therapeutic effect in 6-8-year-olds in this study and in another study ${ }^{23}$.

Many authors also pointed to severity of symptoms as a possible predictor of effective treatment ${ }^{13,23}$. In the presence of severe symptoms, both methods are equally effective, and even their combination ${ }^{19}$. However, treatment using AI was somewhat delayed, in comparison with the use of desmopressin ${ }^{19}$. This can be explained by the fact that desmopressin has a direct effect on the water balance within 30 minutes after administration. Action of AI is associated with the development of neural-reflex connections in response to an external stimulus and this requires, as a rule, several weeks.

A new and significant result of our study is the evidence that a high incidence of independent awakenings is associated with the significant decrease in the number of EE when applying AI, but does not affect the result of treatment among children taking desmopressin. In databases such as Scopus, WoS and PubMed, we were not able to locate studies on frequency of awakenings as an independent predictor for the effectiveness of PMNE. However, we can assume that children, who often awaken when urinating in a dream, already have a specific reflex arc, and parameters of sleep do not impede the realization of a conditioned reflex to awakening at full bladder. In this situation, only a small additional external stimulus is required to fix the existing conditioned reflex. At the same time, use of desmopressin increases the adaptive capacity, but does not affect the fixation of the conditioned reflex. In addition, we understand that this is only one possible explanation of the mechanisms for realizing the therapeutic effect and they certainly need further studies.

This study is not free of limitations. We did not investigate predictors of PMNE treatment effectiveness in individuals treated with the combination of AI and desmopressin, who received imipramine and some other alternative therapies. The range of investigated markers of the socioeconomic and clinical status of patients was also incomplete. These issues require further study and interpretation.

\section{Conclusions}

Predictors of the successful treatment of PMNE with AI are high frequency of independent awakenings from urge to urinate, early age (6-8 years) and severity of symptoms. These predictors, with the exception of the high incidence of independent awakenings are favourable prognostic factors in making effective use of desmopressin. At the same time, the sex, presence of siblings, completeness of the family, level of family income, formation of parents, place of residence, clinical characteristics of urination have no significant influence on treatment outcomes of PMNE. 


\section{References}

1. Karničnik K, Koren A, Kos N, Varda NM. Prevalence and quality of life of Slovenian children with primary nocturnal enuresis. International Journal of Nephrology 2012; 2012:509012.

https://doi.org/10.1155/2012/509012

PMid: 22934181 PMCid: PMC3426229

2. Fockema MW, Candy GP, Kruger D, Haffejee M. Enuresis in South African children: prevalence, associated factors and parental perception of treatment. $B J U$ International 2012; 110(11 Pt C):E111420.

https://doi.org/10.1111/j.1464410X.2012.1 1416.x

PMid: 22958477

3. Su MS, Li AM, So HK, Au CT, Ho C, Wing YK. Nocturnal enuresis in children: prevalence, correlates, and relationship with obstructive sleep apnea. Journal of Pediatrics 2011; 159(2):238-42. https://doi.org/10.1016/j.jpeds.2011.01.03 6

PMid: 21397910

4. Aljefri HM, Basurreh OA, Yunus F, Bawazir AA. Nocturnal enuresis among primary school children. Saudi Journal of Kidney Diseases and Transplantation 2013; 24(6):1233-41.

https://doi.org/10.4103/1319-2442.121312

PMid: 24231492

5. Yazici CM, Nalbantoglu B, Topcu B, Dogan C. Prevalence of nocturnal enuresis and associated factors in schoolchildren in Western Turkey. Canadian Journal of Urology 2012; 19(4):6383-8.

PMid: 22892263

6. Vande Walle J, Rittig S, Bauer S, Eggert P, Marschall-Kehrel D, Tekqul S. Practical consensus guidelines for the management of enuresis. European Journal of Pediatrics 2012; 171(6):97183.

https://doi.org/10.1007/s00431-012-1749-

$\mathrm{x}$

PMid: 22362256

7. Harari MD. Nocturnal enuresis. Journal of Paediatrics and Child Health. 2013; 49(4): 264-71.

https://doi.org/10.1111/j.14401754.2012.0

2506.x

PMid:22846112
8. Bascom A, Penney T, Metcalfe M, Knox A, Witmans M, Uweira T, et al. High risk of sleep disordered breathing in the enuresis population. Journal of Urology 2011; 186(4 Suppl):1710-3.

https://doi.org/10.1016/j.juro.2011.04.017 PMid:21862067

9. Norfolk S, Wootton J. Nocturnal enuresis in children. Nursing Standard 2012; 27(10):49-56.

https://doi.org/10.7748/ns.27.10.49.s55

PMid:23243820

10. Schulz-Juergensen S, Langguth A, Eggert P. Effect of alarm therapy on conditioning of central reflex control in nocturnal enuresis: pilot study on changes in prepulse inhibition (PPI). Pediatric Nephrology 2014; 29(7):1209-13. https://doi.org/10.1007/s00467-014-27560

PMid: 24488507

11. Ferrara P, Del Volgo V, Romano V, Scarpelli V, De Gara L, Miggiano GA. Combined dietary recommendations, desmopressin, and behavioral interventions may be effective first-line treatment in resolution of enuresis. Urology Journal 2015; 12(4):2228-32. PMid: 26341763

12. Berkenwald A, Pires J, Ellsworth P. Evaluating use of higher dose oxybutynin in combination with desmopressin for refractory nocturnal enuresis. Journal of Pediatric Urology 2016; 12(4):220.e1-6. https://doi.org/10.1016/j.jpurol.2016.05.02 9

PMid: 27373215

13. Kosilov K, Loparev S, Ivanovskaya M, Kosilova L. Decrease of risk of developing symptoms of OAB in elderly men and women treated with loop diuretic for hypertensive disease using solifenacin. Current Aging Science 2014; 8(3): 229 34.

14. Kosilov K, Loparev S, Ivanovskaya M, Kosilova L. Comparative effectiveness of combined low- and standard-dose trospium and solifenacin for moderate overactive bladder symptoms in elderly men and women. Urologia Internationalis 2014; 93: 470-3. https://doi.org/10.1159/000363658 PMid: 25170796 
15. Kosilov KV, Loparev SA, Ivanovskaya MA, Kosilova LV. Comparative effectiveness of combined high-dosed Trospium and Solifenacin for severe OAB symptoms in age-related aspect. International Journal of Urological Nursing 2015; 9(2): 108-13. https://doi.org/10.1111/ijun.12076

16. Fujinaga S, Nishizaki N, Ohtomo Y. Initial combination therapy with desmopressin, solifenacin, and alarm for monosymptomatic nocturnal enuresis. Pediatrics International 2017; 59(3):3834.

https://doi.org/10.1111/ped.13212

PMid: 28317303

17. Önol FF, Guzel R, Tahra A, Kaya C, Boylu U. Comparison of long-term efficacy of desmopressin lyophilisate and enuretic alarm for monosymptomatic enuresis and assessment of predictive factors for success: a randomized prospective trial. Journal of Urology 2015; 193(2):655-61.

https://doi.org/10.1016/j.juro.2014.08.088

PMid: 25158273

18. Ahmed AF, Amin MM, Ali MM, Shalaby EA. Efficacy of an enuresis alarm, desmopressin, and combination therapy in the treatment of Saudi children with primary monosymptomatic nocturnal enuresis. Korean Journal of Urology 2013; 54(11):783-90. https://doi.org/10.4111/kju.2013.54.11.78 3

PMid: 24255762 PMCid: PMC3830973

19. Kosilov KV, Loparev SA, Ivanovskaya MA, Kosilova LV. Night diuresis stimulation increases efficiency of alarm. Journal of Pediatric Urology 2015; 11(5): 261.e1-261.e5. https://doi.org/10.1016/j.jpurol.2015.03.01 6

PMid: 26028182

20. Kosilov KV, Loparev SA, Ivanovskaya MA, Kosilova LV. Sensibility of children of different age groups to alarm intervention for enuresis. Journal of Nepal Paediatric Society 2015; 35(1):49-56. https://doi.org/10.3126/jnps.v35i1.11261

21. Van Herzeele C, Evans J, Eggert P, Lottmann H, Norgaard JP, Vande Walle J. Predictive parameters of response to desmopressin in primary nocturnal enuresis. Journal of Pediatric Urology 2015; 11(4):200.e1-8. https://doi.org/10.1016/j.jpurol.2015.03.00 7

PMid: 26059526

22. Ferrara P, Vena F, Basile MC, Ianniello F, Gatto A. Focus on desmopressin and enuresis: a review of literature. Minerva Urol Nefrol 2016; 68(1):14-9.

PMid: 24990391

23. Nevéus T. Nocturnal enuresis-theoretic background and practical guidelines. Pediatric Nephrology 2011; 26(8):120714.

https://doi.org/10.1007/s00467-011-17628

PMid:21267599 PMCid:PMC3119803

24. Kwak KW, Park KH. Clinical inconsistency of lower urinary tract symptoms between questionnaire and bladder diary in children with nocturnal enuresis. Journal of Urology 2008; 180(3):1085-9. https://doi.org/10.1016/j.juro.2008.05.053 PMid: 18639291 